for permission to retrieve the minute books from the National Archives. This took several weeks. Once permission was granted, I then had to get the committee to request the records from the Office of the Clerk which in turn secured the materials from the National Archives. After two months of negotiations, I was finally able to gain limited access (no xeroxing was allowed) to the minute books, but it was worth the effort.

Dealing with congressional staff and the records they control can be frustrating and time consuming. However, there are organizations and individuals who are more than willing to help a dedicated and resourceful scholar gain the information he or she is seeking. Plan your research trip with an eye toward the possible problems that may delay, or even frustrate, your efforts to gain information. Contact those agencies or individuals (Archives, Senate Historian, House Clerk, relevant committees or appropriate members of Congress) who might smooth your path before you embark on your project. Let them know your interests, then solicit their advise or support. You may be pleasantly surprised with the support you get if you approach the process in the correct way. Scholars will find that the value of congressional records will surely justify the effort required to obtain them.

\section{Notes}

1. Those interested in researching former members need to refer to the two superb reference works published by Congress as part of the bicentennial celebration. The first is House Doc. No. 100-171, A Guide to Research Collections of Former Members of the United States House of Representatives 1789-1987. The second is Senate Doc. 97-41, Guide to Research Collections of Former United States Senators 1789-1982.

2. Nelson $(1980,78)$ reports that the Clerk automatically excludes access to minutes of executive sessions and papers marked "confidential." I have made numerous requests of committee minute books, and have never been denied access provided they are at least fifty years old.

3. You can forget going to court to obtain the records if the Clerk denies access, since the records of Congress are not subject to the provisions of the Freedom of Information Act.

\section{Reference}

Nelson, Anna K. 1980. "Disorder in the House: The Inaccessible Record," The Public Historian 2:73-83.i.

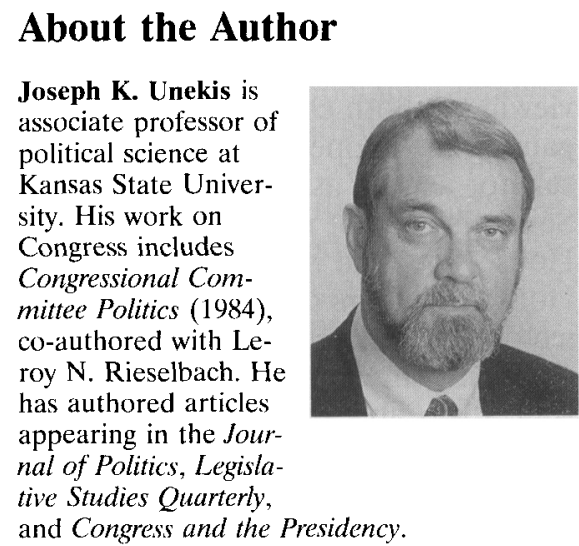

\title{
Ratings and Rankings: Some Important But Slighted Aspects
}

\author{
Albert Somit, Southern Illinois University
}

The several $P S$ articles recently (Spring, 1996) devoted to ranking and rating political scientists and political science departments evoked a by now familiar mix of emotionsfeelings perhaps akin to those experienced by Dr. Frankenstein when, as the circumstances permitted, he pondered both his scientific accomplishment and the consequences thereof.

As some of $P S^{\prime}$ older readers may recall, Joe Tanenhaus and I were the first to undertake a study, utilizing responses from a sizable sample of the profession, of perceived departmental quality and of individual scholarly achievement (the so-called "Hall of Fame") (Somit and Tanenhaus, 1964). Needless to say, we were reasonably confident that these ratings and rankings would be of interest to the profession. We did not anticipate, however, the degree of that interest, the continuing controversies the rankings evoked, or the number of studies to which these controversies subsequently gave rise. Nor, surely, did we ever dream of the methodological ingenuity which would be brought to bear in what has since become almost a small scale cottage industry.

Now, three decades later, I wonder whether other disciplines have given so much attention to these matters; or, worse, how much political science itself has benefitted thereby. Understandable pride in being a pioneer is thus often alloyed by an equally understandable twinge of guilt.

These misgivings aside, the latest $P S$ pieces once again reminded me that, despite a literature which now numbers perhaps a score of items, two important aspects of ratings and rankings have not received the atten- tion I believe they deserve. One of them, dealing with the career consequences of departmental reputation, has been slighted; the other, related to individual achievement, has to the best of my knowledge been totally ignored.

\section{Political Science: Still A Caste-Characterized Profession?}

First, the career consequences of departmental reputation. As Tanenhaus and I reported in a subsequent publication (1967), political science was then clearly a two-caste profession: the Brahmins were those who had taken their doctorates at one of the "distinguished" departments; in the other and much larger caste ("Untouchables"?) were those who had not. Thus, of the sixteen "leading" members of the profession who 
held American doctorates, fifteen came from one of the "distinguished" (top twenty) departments; graduates of a "top ten" department accounted for 80 percent of the articles in the Review and 70 percent of those in the Journal of Politics. And, confirming an already widely-held impression, we found that

... persons with "prestige" doctorates have a near-monopoly of faculty posts at the best schools. "Distinguished" departments are manned almost exclusively by graduates of "distinguished" departments. Roughly speaking, the odds are about 10 to 1 that someone on the faculty of a highly rated [graduate] department took his doctorate at one or another of the top-ranking departments. The same situation prevails at the best colleges (1967:166).

In the intervening three decades, of course, there have been some major changes. Brahmins no longer have a near-monopoly on journal publication although, depending on the measure utilized, a case might be made that they are at least numerically "over-represented." Turning to employment, women and minorities, conspicuously rare in our ranks in the $1960 \mathrm{~s}$, have become an increasingly important component of the profession.

There are, however, two by no means trivial aspects of faculty staffing about which we still have little hard information. In hiring women and minorities, have the leading departments perpetuated their previous policy of recruiting almost exclusively from other leading departments or, at least in this respect, have the barriers been lowered? And, extending the question much further, has there been any significant receptivity among the leading departments to the appointment of white males with "second class" doctorates-or is the caste system still holding firm?

The answers to these questions, I think we would all agree, have profound implications for the profession both collectively and individually. If the caste system has been weakened to any appreciable degree, this would surely brighten the career prospects of those with degrees from non-prestigious departments-and it is these departments which now turn out a majority of our Ph.D.s. If, however, the barriers are still up ... Surely, we should then seriously consider the possible consequences both for these graduates, and for the departments that produce them, as we face an era in which "downsizing" may become as familiar and dreaded a term in academia as it has in business and industry.

\section{Intellectual Impact: Inter- or Intra-Disciplinary?}

Now for the second and perhaps intellectually more important issue. There have been, of course, numerous studies of individual achievement and reputation (i.e., Hall of Fame). But so far as I know, all of these studies have examined reputation and influence within the profession, that is, among political scientists. To be sure, it is interesting and possibly substantively valuable to know which of our colleagues are most highly regarded by their fellow practitioners; those who do well by this metric can justifiably be proud.

Nonetheless, for scholars and scientists there are other and arguably even more impressive levels of achievement. One of these, obviously, is impact beyond the boundaries of one's discipline. For a political scientist, for example, this would entail recognition not only among political scientists but also among (some combination of) practitioners in the other social and behavioral sciences-anthropology, economics, history, psychology, sociology, conceivably even law.

At another rung on the ladder, and quite often outside of academia, are those who, via articles, books, speeches, radio, television, and other media, play an important role in shaping popular thought. These are the individuals whose names are known by the informed layman and whose ideas and proposals are frequently reflected in debates about public policy, or even actually incorporated therein.

We can all think of individuals in other fields whose influence has been felt well beyond their own discipline. Who are their counterparts in political science? How, moving to the main concern, does political science compare in this respect with its sister disciplines? The answers to these questions might tell us, I suggest, not only a great deal about our status as a social and behavioral science (back to ratings and rankings) but, more important, a great deal about our profession's strengthsand possibly its weaknesses.

In short, departmental ratings and individual rankings, albeit interesting, are of themselves not necessarily of great substantive significance. Approached from a somewhat different direction, however, they have the potential for providing information that can be put to more constructive purpose than has sometimes been the case to date. That, not to belabor the point, is why I would propose that these two aspects of disciplinary reputation not be indefinitely neglected.

\section{References}

Somit, Albert and Joseph Tanenhaus. 1963. American Political Science: A Profile of a Discipline. New York: Atherton Press.

The Development of American Political Science. 1967. Boston: Allyn and Bacon.

\footnotetext{
About the Author

Albert Somit is Distinguished Service Professor at Southern Illinois University at Carbondale.
} 